\title{
Type 2 Diabetes Mellitus: a reciprocal mutual interaction with amyloidosis or a presentation of an isolated primary pancreatic amyloidosis?
}

\author{
Mina T. Kelleni* \\ Pharmacology department, Faculty of medicine, Minia University, Egypt
}

In two previous editorials, I've explored some evidence linking type 2 diabetes mellitus (T2DM) to the cytotoxicity of islet amyloid polypeptide aggregates deposited in pancreas and I've expressed a strong wish and call to focus on the full of potentials amyloid research as well as on drug development of amyloid antagonists. In this short commentary, I'm trying to search deeper on the relationship between both diseases and whether T2DM can be a consequence of pancreatic amyloidosis $[1,2]$.

Primary amyloidosis was shown to be particularly difficult to diagnose because its signs and symptoms are subtle and because of the absence of specific imaging or laboratory tests, except histopathology [3]. Meanwhile, secondary amyloidosis has been shown to complicate chronic inflammatory autoimmune diseases [4] and chronic diseases such as autoimmune disease and T2DM have also been suggested to be potential factors for AA amyloidosis [5]. Thus, a reciprocal interaction may be also involved; several cases of insulin-derived localized amyloidosis have been reported like those mentioned in [6,7] and a case of primary systemic amyloidosis with the history of T2DM for nine years has also been recently described [8]. Further, Inflammation is known to be closely involved in the pathogenesis of T2DM, and reactive amyloidosis occurs in the presence of chronic inflammation and renal AA amyloidosis was shown to be prevalent in T2DM [9].

I finish this short commentary by referring to one of the first articles published seven years ago and pointed to this important debate; I'll repeat the authors call for a substantial more work to elucidate the association and/or causation between both diseases; I totally agree with what they've written: "keeping an open mind on the nature of the cytotoxic insult has implications for therapeutic developments and clinical care in type 2 diabetes" [10].

\section{References}

1. Kelleni MT (2016) Amyloid Antagonists: The Future of Type 2 Diabetes as Well as Several Neurodegenerative Diseases Treatments. Diab Obe Int J1: 000106.

2. Kelleni MT (2016) Amyloid Deposits: a Possible Link between Type 2 Diabetes Mellitus and Cancer. Diab Obes Int J1: 000131.

3. Ye L, Shi H, Wu HM, Wang FY (2016) Primarily isolated hepatic involvement of amyloidosis: A case report and overview. Medicine (Baltimore) 95: e5645. [Crossref]

4. Rao RR, Yong WC, Wasko MC (2016) Systemic Light Chain Amyloidosis Mimicking Rheumatic Disorders. Case Reports in Medicine2016: 7649510.

5. Maeda M, Murakami T, Muhammad N, Inoshima Y, Ishiguro N (2016) Experimental transmission of systemic AA amyloidosis in autoimmune disease and type 2 diabetes mellitus model mice. Exp Anim 65: 427-436. [Crossref]

6. Okamura S, Hayashino Y, Kore-Eda S, Tsujii S (2013) Localized amyloidosis at the site of repeated insulin injection in a patient with type 2 diabetes. Diabetes Care36: e200. [Crossref]

7. Shiba M, Kitazawa T (2016) Progressive insulin-derived amyloidosis in a patient with type 2 diabetes. Case Reports Plast Surg Hand Surg 3: 73-76. [Crossref]

8. Yin Q, Fan Y, Tang X, Li L, Zeng Y, Liao H, et al. (2016) A Case of Primary Systemic Amyloidosis and Type 2 Diabetes Presenting with Nephrotic Syndrome and Recurrent Periorbital Purpura. West Indian Med J. [Crossref]

9. Diez R, Madero M, Gamba G, Soriano J, Soto V (2014) Renal AA Amyloidosis in Patients with Type 2 Diabetes Mellitus. Nephron Extra4: 119-126. [Crossref]

10. Zraika S, Hull RL, Verchere CB, Clark A, Potter KJ, et al. (2010) Toxic oligomers and islet beta cell death: guilty by association or convicted by circumstantial evidence? Diabetologia 53: 1046-1056. [Crossref]
Copyright: (C)2016 Murakami M. This is an open-access article distributed under the terms of the Creative Commons Attribution License, which permits unrestricted use, distribution, and reproduction in any medium, provided the original author and source are credited.
Correspondence to: Mina T. Kelleni, Pharmacology department, Faculty of medicine, Minia University, Egypt, Tel: (+20) 1200382422; E-mail: drthabetpharm@yahoo.com

Received: December 28, 2016; Accepted: January 24, 2017; Published: January 27, 2017 